OPEN ACCESS

Edited by: Heping Xu,

Queen's University Belfast, United Kingdom

Reviewed by:

Andrew W. Taylor,

School of Medicine, Boston University,

United States

Ankush Kawali,

Narayana Nethralaya, India

*Correspondence:

John V. Forrester j.forrester@abdn.ac.uk

Specialty section: This article was submitted to Inflammatory Eye Diseases, a section of the journal Frontiers in Ophthalmology

Received: 03 February 2022 Accepted: 15 February 2022

Published: 08 March 2022

Citation:

Forrester JV, Mölzer C and Kuffova L (2022) Immune Privilege Furnishes a Niche for Latent Infection.

Front. Ophthalmol. 2:869046. doi: 10.3389/fopht.2022.869046

\section{Immune Privilege Furnishes a Niche for Latent Infection}

\author{
John V. Forrester ${ }^{1 *}$, Christine Mölzer ${ }^{1}$ and Lucia Kuffova ${ }^{1,2}$ \\ 1 Ocular Immunology Group, Section of Infection and Immunity, Institute of Medical Sciences, University of Aberdeen, \\ Aberdeen, United Kingdom, 2 Eye Clinic, Aberdeen Royal Infirmary, Aberdeen, United Kingdom
}

The microenvironment of the CNS (eye and brain) is fertile ground for infection if the barriers are breached. The result of pathogen invasion is often devastating destruction of tissues. In the eye, inflammation is broadly classified either as "infectious" (i.e. caused by infection) or "non-infectious". However, increasingly, forms of intraocular inflammation $(\mathrm{IOI})$, which clinically appear to be "non-infectious" turn out to be initiated by infectious agents, suggesting that pathogens have been retained in latent or persistent form within ocular tissues and have reactivated to cause overt disease. A similar pathogenesis applies to latent infections in the brain. Not all CNS tissues provide an equally protective niche while different pathogens escape detection using different strategies. This review summarises how immune privilege (IP) in the CNS may be permissive for latent infection and allow the eye and the brain to act as a reservoir of pathogens which often remain undetected for the lifetime of the host but in states of immune deficiency may be activated to cause sight- and life-threatening inflammation.

Keywords: uveitis, retina, CNS, barrier, microbe, tolerance, intraocular inflammation, latency

\section{INTRODUCTION}

The host-pathogen interaction is not an easy one. Either the host or the pathogen fails to survive. A good outcome for the host is one in which the pathogen is completely cleared. Whether this is achieved depends on the fitness of the host and the potential for the pathogen to wreak damage (virulence). Less virulent pathogens have evolved strategies to evade the host's immune defences, and these are variously described as latency, dormancy, persistence, or immune evasion. This ensures species survival for the pathogen assisted by a conducive host environment.

Hosts are generally complex organisms comprised of multiple parts (tissues) each with varying levels of host defence capability, an immunological feature described by Matzinger as "tissue-based" control of the immune response (1). This may be further modulated in chronic/persistent infection in that the infected tissue might alter host immune cell behaviour, for instance towards effector memory T cell exhaustion (2) or increased T regulatory [Treg] cell activity $(3,4)$. Central nervous system (CNS) tissue (eye and brain) is known to modify the immune response, a property attributed to its "privileged" status (immune privilege, IP). Although all tissues exhibit IP to varying degrees, in the eye and the brain IP's immunomodulatory properties are maximised (5). This review considers the possibility that the IP status of the CNS offers pathogens special license to evade the immune system, often for the lifetime of the host, by promoting latency. 


\section{IMMUNE PRIVILEGE IS ONE FORM OF IMMUNOLOGICAL TOLERANCE}

The concept of IP developed as an explanation for a phenomenon that did not fit with the emerging dogma on immunological tolerance (IT). IT, as a theory, developed from studies of allograft rejection and the discovery of MHC antigens, and was formulated on the notion of self-non-self-discrimination (SNSD) (6). Immunity to foreign antigens was viewed predominantly in terms of the specificity of adaptive immune responses and SNSD-based IT was the process whereby the immune system avoided $\mathrm{T}$ and $\mathrm{B}$ cells turning on the host.

SNSD-based IT is described mechanistically as central (thymus-based) or peripheral, both of which occur mainly through three mechanisms: deletion, anergy or regulation $(\mathrm{T}, \mathrm{B}$ reg) of self-reactive effector $\mathrm{T}$ and $\mathrm{B}$ cells [reviewed in $(7,8)$ ]. However, the SNSD paradigm did not appear to apply to the eye where (non-self) skin allografts placed in the anterior chamber of the eye were accepted despite rejection of the same allograft in the skin (9). Accordingly, IP was coined as a term to describe this unique property of the CNS (similar allografts in the brain were accepted) and was extended to include foreign antigens generally [reviewed in (10)] although this has been debated with regard to infectious agents (11-13).

The original SNSD theory did not apply to the primary (innate) immune defence system which was considered to respond nonspecifically to foreign antigens. However, when innate immune cells were found to display selectivity in their responses to different classes of pathogens and toxins (pathogen- or damage-associated molecular patterns: PAMPs, DAMPs) the role of innate immune cells as drivers of adaptive immunity became clear $(14,15)$. Thus the "Danger" or "Damage" model was formulated in which the immune system responds to pathogenic stimuli through innate immune cell recognition of PAMPs/DAMPs by pattern recognition receptors (PRR) and presents the engulfed and processed antigens to adaptive immune cells. In addition, activated $\mathrm{T}$ and $\mathrm{B}$ cells not only clear pathogens (e.g. CD8 cytotoxic T cell killing of virus-infected cells) but also generate antigen-specific memory cells (16). All antigens, including self-antigens, can thus potentially activate the immune system but only do so in the right context (co-stimulation) and microenvironment.

Immune responses are therefore highly context-dependent and the role of the tissues as the site of host-pathogen encounter is also recognised (1). Under normal circumstances, the overwhelming majority of antigens (foreign and self) do not induce a clinically detectable tissue-damaging immune response, as evidenced by the enormous range of harmless commensal antigens, plus the potential innumerable self-antigens, and if they do so, the tissue has the capability to modify the outcome and restore homeostasis (17). However, host-microbe interactions are not binary in their responses since several outcomes are possible. From a conceptual point of view, the host-microbe relationship has thus been re-branded as the damage-response framework (DRF) to encapsulate the range of interactions and includes five existential microbial states within a host: infection, colonisation, commensalism, disease and latency (18).
When immune responses in the eye are considered in this context, it offers an explanation for IP: the microenvironment of the eye is not conducive to "conventional" immune responses as occur in the skin and achieves this state using the same mechanisms as IT, namely deletion [e.g. Fas/FasL, TRAIL/ TRAIL-Rs (1-4), CTLA-2 $\alpha /$ PDL-1 [ (19-22)], anergy $(23,24)$ and $\mathrm{T} / \mathrm{Breg}$, controlling both innate and adaptive immune responses (25-27). Robust, conventional immune responses, for instance in the lung, the gut or the skin, have a good chance of clearing the infection and restoring tissue homeostasis in an otherwise healthy individual. In contrast, the attenuated immunity of IP does not seem to be very effective either in clearing the infection or preventing intraocular inflammation (IOI) [uveitis is a significant cause of blindness, www.who.int/blindness (28)]. Moreover, IP has not been demonstrated convincingly for infectious foreign antigens [reviewed in (5)]. In fact, when infectious agents invade the eye the extent of tissue damage can be catastrophic. But this is not always the case; some cases of intraocular inflammation caused by infectious agents [such as toxoplasma-associated uveitis (29)] can resolve. Furthermore, apparent non-infectious causes of intraocular inflammation are just about as frequent as infectious causes. How is this explained?

\section{INTRAOCULAR INFLAMMATION}

\section{Aetiology}

Intraocular inflammation is a rag bag of conditions, described often by their clinical presentation but also by the causative agent. Etiologically, IOI is described as infectious when an infectious agent can be detected, isolated, and/or cultured from the intraocular compartment/tissues and is seen to be the cause of tissue damage. Molecular diagnostics are increasingly helpful in detecting microbes (30). "Infectious" in general terms implies transmissibility but this does not occur in IOI unless the ocular surface and the surrounding adnexae are involved as in herpes zoster ophthalmicus (31) and SARS-CoV-2 conjunctivitis (32). For instance, cataract surgery in survivors of the highly infectious Ebola virus (33) did not lead to transmission of disease even though they had recent signs of IOI (34). Rarely, infectious agents can be transmitted via corneal allografts in unsuspected donor infection [e.g. Chikungunya (35), herpes simplex (36), and prion disease (37)] but this does not come under the typical classification of "infectious" IOI. In contrast, non-infectious IOI is the label for conditions in which no infectious agent can be detected.

\section{Clinical Presentations}

The Standardisation of Uveitis Nomenclature (SUN) working group has sought to bring order to the descriptors for the range of syndromes collected under the umbrella of IOI, and defined sets of clinical criteria have been proposed for each condition mainly to facilitate a bioinformatic approach to clinical studies (38). The initial SUN criteria are based on anatomical descriptions relating to the location of the primary site of 
inflammation in the eye (39). The more recent subset classification has necessarily been more restrictive, and some cases of IOI will not fit the criteria for any specific clinical entity. However, the overarching concept retains the possibility that some individual conditions can present in a variety of ways such as tuberculous or syphilitic IOI and that pathogenetic tissuedamaging processes are common to many of the conditions. This is important to realise since the level of inflammation and damage varies with the tissue involved and its intrinsic degree of tissue tolerance (IP) (5).

\section{Privileged Tissues Involved}

We, and others (40-42), have argued that IP is relative: some tissues exert greater control over immune responses compared to others and that this applies particularly to CNS tissues. Thus, the retina and the brain parenchyma have a range of physical, chemical and immunological barriers which provide a high level of IP while border tissues such as the uveal tract and the meninges, with their rich complement of immune cells and ready access to draining lymph nodes have low levels of IP. The brain parenchyma (and presumably retina) in fact, have connections with the secondary lymphoid tissues (cervical lymph nodes) through drainage of interstitial fluids and cerebrospinal fluid (CSF) via the recently recognised brain glymphatic system and meningeal lymphatics $(5,10,41)$. Tissues such as the cornea and sclera have intermediate levels of IP, mainly due to their low vascularity and limited expression of MHC molecules (43) as well as their content of immunomodulatory mediators (21). Indeed, corneal IP is readily rescinded by infection (44).

\section{LATENT INFECTION AS A CAUSE OF INFECTIOUS UVEITIS}

Microbial latency is described operationally as a state "in which host damage that occurs does not perturb homeostasis to a degree that results in clinical disease" (45). An important difference between colonisation and latency is time: colonising microbes are eventually cleared or cause overt disease while latent microbes usually persist for the lifetime of the host, frequently without causing disease as for instance with Epstein Barr virus (EBV).

Latent infections can be caused by a wide range of microorganisms and occur in many sites. They have a predilection for residency in the CNS, either in parenchymal tissues per se or in the brain and eye border regions (meninges and uveal tract) (10). The following sections illustrate various forms of microbial latency in the CNS and eye.

\section{Fungi}

Several species of fungi can cause damaging inflammation in the eye and brain including Cryptococcus neoformans, Aspergillus spp., Histoplasma capsulatum, and Fusarium sp. Fungi are typically not dependent for replication on a mammalian host and usually survive and replicate environmentally. While many infections are exogenous, some are endogenous and occur only when the host is immunosuppressed, suggesting that the microbe is reactivated from a "dormant" state after subclinical invasion. Fungi require two conditions to establish overt tissue-damaging infection: dormancy and immunosuppression (46). Cryptococcus neoformans infection is contracted early in life and persists in myeloid cells in granulomas in the lung and draining lymph nodes asymptomatically. How they are released from infected lymph nodes to enter the circulation is poorly understood but they invade the CNS when they have passed from the circulation into the CNS border regions (uveal tract and meninges). Access to the retina and brain is usually via direct passage across the $\mathrm{BBB} / \mathrm{BRB}$ (transcytosis) or more commonly, inside migratory leukocytes (Trojan Horse mechanism) (47).

How fungi achieve a state of dormancy (a state of greatly slowed but still functioning metabolism) varies somewhat with each organism. For instance, C. neoformans may be inhaled either as yeast or a spore, but while yeasts are killed after phagocytosis by lung macrophages, spores only weakly stimulate PRRs and so can persist for long periods of time in macrophages and dendritic cells within granulomas (48). Granuloma formation is an important mechanism in controlling C. neoformans and involves IFN $\gamma$ - producing Th1 cells within the lesion. Yeast glucuronoxylomannan (GXM, 80\%) and galactoxylomannan (GalXM, 10\%) are the major capsular polysaccharides which influence the immune responses (49). As for the lung, it is likely that C. neoformans-containing uveal and meningeal granulomas persist for long periods undetected (latent infections) until protective immunity ( CD4/CD8/NK cell) declines to a point where it fails to prevent extrusion of replicating fungi from macrophages and entry into the CNS parenchyma. The fungus may also contribute to this process since GXM, shed from yeast has immunosuppressive properties, reducing immune cell entry into the CNS (50). In addition, fungal urease seems to be required for invasion of the CNS [reviewed in ref (51)].

Other fungi which cause endogenous CNS infections, such as Aspergillus, may follow a similar pattern of pathogenicity of latency/dormancy and disease when immune control declines (52). They may even invade the CNS locally along nerve endings from the paranasal sinuses through cribriform plate (53-56) a route also taken by some viruses such as Ebola and SARS-CoV-2 COVID -19 (see below). Pneumocystis carinii occurs in normal lung tissue and does not usually cause pneumonia unless the patient is severely immunocompromised $(57,58)$. Spread to the choroid can then occur to cause disease. Whether it can reside latently in choroidal macrophages is not known. However, fungi generally such as Candida (the most common fungal infection), Fusarium and Mucorales probably do not fall into the category of latent infections, unless they have progressed through a barrierbreaching invasive phase of infection e.g. in the lungs or gut, and have reached a second stage of immune evasion by persistence as dormant microbes within myeloid cells, controlled by an adaptive immune response. In the absence of this process, they are better considered to be commensals, symbionts or parasiticbut-potentially-infectious agents as defined by the DRF (18).

\section{Parasites/Nematodes/Helminths}

Toxoplasma gondii (Tg) is the most common parasitic infection of the eye and in some regions such as Brazil is the commonest cause of IOI (59). Infection is acquired at any age mostly through 
ingestion of infected meat. Serological evidence of exposure to $\mathrm{Tg}$ increases with age and in some countries can reach levels of 80 $90 \%$ of the population. However, most individuals are asymptomatic, or experience only a mild GI disturbance $(60,61)$.

Ingestion of Tg cysts (bradyzoites/oocysts) leads to the release of large numbers of tachyzoites on contact with digestive enzymes which rapidly invade the blood and lymphatic circulations. Tachyzoites disseminate freely or inside infected dendritic cells induced by the Tg 14-3-3 protein (62), and generate a marked IFN $\gamma$ Th1 response in draining lymph nodes. Both free or leukocyteinternalised tachyzoites invade muscle tissue and cross the BRB/ $\mathrm{BBB}$ to infect neurons where they are induced to transform to bradyzoites via formation of a parasitophorous vesicle. In this state they are considered to have entered a prolonged phase of latency, but in fact there is a low level of Tg replication within bradyzoites (63). Replication is inhibited by the continuous production of antigen-specific CD8 T cells which require CD4 T cells to "help" their generation (64). Reactivation of latent CNS Tg thus depends on failure of both CD4 and CD8 T cell responses (65). In addition, recent studies in Balb/c mice have shown that a specific peptide from Tg, Gra6, binds an unusual MHC Class I molecule, MHC-1 L (d), to enhance CD8 T cell protection against Tg reactivation (66, 67). Other cells are also involved in this CNS protective response: astrocytes and oligodendrocytes release IL33 in Tg infected brains (66) and probably also in Tg infected eyes (68), and is required for control of infection via chemokine-induced recruitment of immune cells, while microglial production of gasdermin adds a further layer of immune protection (69). Thus, the complexity of the immunological machinery required to keep $\mathrm{Tg}$ bradyzoites in latency is critically dependent on the CNS microenvironment.

Other latent parasitic infections affecting the eye are unusual. Malaria, giardiasis, leishmaniasis, and trypanosomiasis have all been reported, and ocular disease occurs often long after the initial infection, raising the possibility of an initial asymptomatic infection and sequestration of parasites in the eye. For instance, it is estimated that up to $33 \%$ of patients with giardiasis develop late extraintestinal manifestations including ocular disease (often in the form of retinal vascular occlusion and/or uveitis) and arthritis [reviewed in ref (70).]. The pigmentary degeneration which is characteristic of late ocular disease suggests that the parasite may reside latently in the retinal pigment epithelium (RPE) $(71,72)$.

Numerous other parasites, nematodes, cestodes and trematodes, as well as helminths are known to cause ocular infections [reviewed in ref (73)], but most would not be classified as latent infections. However, they often induce minimal inflammation as in the case of intraocular loiasis (74) or in cases of DUSN (75) prior to onset of symptoms, and the invading parasites (e.g. Loa loa) might be regarded as having a symbiotic, mutualistic or even a commensal relationship with the intraocular compartment. In another tissue, such parasites would likely induce a vigorous immune response and be rapidly cleared by the immune system.

\section{Viruses}

A large number of viruses, both DNA and RNA, are recognised to establish latent CNS infections and cause CNS inflammation and IOI when reactivated. Top of the list are herpes viruses including HSV-1 and HSV-2, VZV, CMV and EBV. Herpes viruses have tropism for particular cells (neurons: HSV, VZV; myeloid cells: CMV; B cells: EBV; T cells: HIV) and reside in CNS cells or in leukocytes populating the CNS border regions (uvea, meninges). They infect neighbouring cells by shedding virus-containing exosomes (76). CMV establishes latency in haemopoietic cells and renders them inactive/anergic (77) thereby promoting latency (78). Reactivation of most DNA viruses occurs in immunosuppressed or immunodeficient patients indicating that latency and control of reactivation is actively mediated by the immune system. Interestingly, as for parasites, control is achieved through CD8 T cell activity (79).

EBV has been implicated in the pathogenesis of multiple sclerosis (MS) for many years. Despite evidence of EBV in the brains of MS patients (80), resistance to this concept has been long standing $(81,82)$ in part because EBV infection is so ubiquitous [EBV seropositivity is present in over $\sim 85 \%$ of the population (83)]. However, a recent extensive study in US military personnel of the relationship between EBV antibody seroconversion and newly onset MS strongly suggests that EBV is required as a trigger for MS disease (84), and that certain specific proteins (EBER, EBNA-1) act as molecular mimics of CNS proteins such as glial CAM (85) and anoctamin 2 (86). As indicated above, EBV latently infects B cells, which account for $\sim 20 \%$ of immune cells in the immune cell rich meninges. MS patients consistently develop B cell granulomas in the meninges which extend into the subarachnoid space and pial meninges lining the cortex where the inflammatory damage and virus spreads to glial cells and oligodendrocytes, eventually affecting axonal transport and neuronal function (87-89). Reactivation of EBV in situ would thus cause extensive damage at the cortical level.

RNA viruses such as Ebola, Chikungunya (90), Rubella (91), Dengue (92), Measles (93), Zika (94) and more recently SARSCoV-2 are known to persist in the CNS and are recognised causes of IOI in survivors from the primary infection (95). Here, the definition of latency is less clear. Current thinking is that such viruses develop persistence (i.e. low-level replication) rather than latency, as in the case of Ebola which persists as a slowly replicating virus in the RPE (96). Even with vaccination, Ebola can persist and reactivate with dire consequences (97).

Latent HIV persists in CNS microglial reservoirs (98) and can cause retinopathy. CNS HIV persistence can impinge negatively on efficacy of treatment (99). The retrovirus HTLV-1, a worldwide cause of IOI $(100,101)$, reactivates when the immunoregulatory aryl hydrocarbon receptor (Ahr) (102) IDO system is functional: reactivation is controlled by the level of Ahr ligands and balanced by persistent activation of NF-кB (103). Thus, this immunoregulatory system, which is active within the immune-privileged eye $(104,105)$, may determine whether HTLV-1 induces uveitis. Like Ebola and RNA viruses generally, HTLV-1 persistence is maintained by low level replication and in the CNS microenvironment is at risk of reactivation. As for most viral infections, HTLV-1 is a "lifelong infection which is never truly silent" (106). 
Interestingly, "subclinical" virus reactivation in the form of viral shedding (for instance in the urine) is a common phenomenon and is exacerbated by many forms of stress (107).

\section{Bacteria}

Mycobacterium tuberculosis (Mtb) is the paradigmatic cause of latent bacterial infection involving the CNS. The disease is contracted as an airborne lung infection and produces two forms: caseating tuberculosis when the organism is replicating and causing tissue necrosis, and immunoreactive TB where replicating Mtb is held in check by a prominent immune response. The latter takes the form of a granuloma, either in the lung or in the draining lymph node (108) and, as for many microbes, the organism evades direct attack by the immune system by residing in myeloid cells (macrophages and DC) where it disables the lysosomal killing machine (109). Viral co-infection promotes survival of Mtb in macrophages by co-opting TNF $\alpha$ to reduce $\mathrm{T}$ cell priming (110). However, intracellular $\mathrm{Mtb}$ proliferation is controlled by a CD4 $\mathrm{T}$ cell response but this is a complex interaction between the host and the pathogen and this immune response may be either protective or pathogenic (tissue damaging) (111). Infected myeloid cells, or, in the absence of CD169, their shed extracellular vesicles (112), escape the granuloma and disseminate to cause extrapulmonary $\mathrm{TB}$ (miliary TB) with a predilection for CNS border tissues. This presents as TB meningitis and choroiditis and is typically contained as a granulomatous immunoreactive inflammation. However, when immune dysregulation looms, caseation and tissue necrosis within a "tuberculoma" can occur (Figure 1). Ocular TB is a classic example of latent infection safely sequestered in macrophages: latent TB IOI disease in its miliary form does not contain replicating bacilli while the choroidal tuberculoma may contain replicating microbes and be "infectious" in the true sense.

TB is widespread: one third of the world's population have been infected with TB, most of whom survive the disease and present with latent TB, demonstrated by a positive skin test (TST, Mantoux) and/or interferon gamma release assay positivity (Quantiferon test). These tests indicate that the patient has been prior infected by Mtb and probably that the tubercle Bacillus is resident in the host with the capability to induce pathology even though the lung may have cleared the infection (113). Latent TB is long-lasting and clearance of Mtb is probably never complete $(113,114)$. Disease reactivation involving the CNS parenchyma occurs particularly in states of relative immunosuppression but is more commonly restricted to the CNS border regions. Despite large numbers of latently infected people, $<10 \%$ develop overt disease: this suggests that persistence of latent $\mathrm{Mtb}$ is the norm in immunocompetent individuals and that the site of latency is frequently the CNS border regions (meninges and uveal tract).

Other latent bacterial infections in the eye are uncommon. Treponema pallidum becomes "latent" (i.e. clinically silent) after resolution of the primary and secondary stages and manifests itself in the tertiary stage in the CNS and eye. During latency, control of spirochete replication is maintained by a robust immune response such that progression from the latent stage to the tertiary stage is not inevitable, occurring in around $15-40 \%$
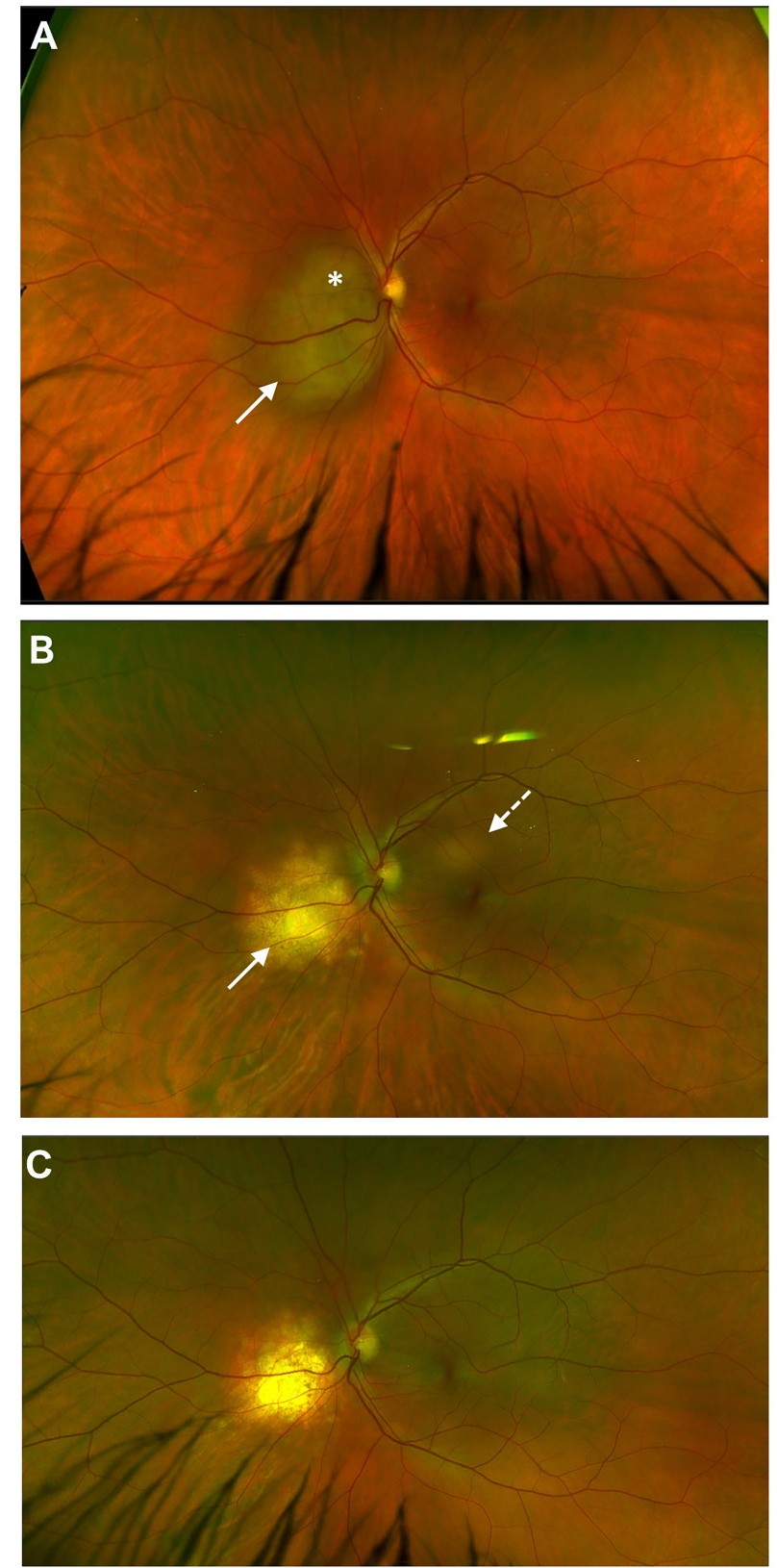

FIGURE 1 | Choroidal tuberculoma* in HIV +ve patient two years after cessation of anti-retroviral therapy. Miliary tuberculosis involving eye (A), CNS, multiple lymph nodes (mediastinum, retroperitoneal) and spleen; regression of initial lesion (white arrow) but appearance of a new lesion (dashed arrow) after six months of anti-TB and anti-retroviral therapy (B); anti-TB therapy stopped at 12 months; complete resolution of both lesions noted at 18 months (C).

of cases (115). Patients in the latent stage who do not progress may have cleared the infection (with the help of antibiotic therapy) but may also harbour non-replicating spirochetes. Interestingly, the spirochete traverses the blood-CSF barrier without causing neurological disease in the early stages (116), resides in the CNS border regions during the latent period (117) 
and can be detected by CSF PCR technology $(118,119)$. The same occurs with Borrelia Burgdorferi, the tick-borne etiologic agent of Lyme disease and a rare cause of IOI (120). Another tick-borne disease, Rickettsia, has been reported to cause "epidemic rickettsia retinitis". Such cases develop as a later event after the primary infection and are diagnosed by the serological FelixWeil test (121). However, such cases probably do not fit the diagnosis of latent infection. Bartonella ssp., a further vector borne pathogen can cause IOI in rare cases, and can present in various forms including serpiginous choroiditis (122). Lastly, certain cell wall deficient and mycoplasma-like organisms have been reported in chronic intermediate uveitis, but their nature is obscure $(123,124)$.

\section{LATENT INFECTION AS A CAUSE OF NON-INFECTIOUS UVEITIS}

A recent study based on insurance claims indicates that $<20 \%$ of cases of uveitis in the US are directly caused by infection (125). In developing countries, the numbers are higher but accurate statistics are difficult to obtain. The conundrum is what causes IOI when no infectious agent can be identified ["non-infectious" or "undifferentiated" uveitis (126)] even with cutting edge molecular diagnostics (127)? Autoimmunity as a cause has fallen from favour mainly due to the lack of evidence for pathogenetic autoantibodies or $\mathrm{T}$ cells different in quality or quantity from those that occur in healthy populations. Similarly, evidence for autoinflammatory mechanisms in IOI is mostly restricted to rare monogenetic syndromes although dysregulated inflammation is gaining traction as an underlying predisposition [reviewed in (126)]. The possibility that infection, either directly or indirectly, causes most if not all forms of IOI and that its aetiology is only masked by the limitation of the diagnostic toolkit warrants consideration. The following paragraphs address some clinical IOI entities.

\section{Intermediate Uveitis}

Intermediate uveitis includes the subgroups pars planitis, vitritis, and the peripheral retinal vasculitis of MS. The retinal parenchyma is not generally involved. All of the above classes of microbes have been associated with intermediate uveitis $(90,128-132)$. Latent tuberculosis has been implicated in peripheral occlusive retinal vasculitis (previously known as Eales' disease) (133-135), while latent EBV infection is a strong candidate for the same pathology in MS $(84,136)$. Pars planitis with or without snowbanking has been linked to parasitic infections such as toxocariasis (137) while vitritis has long been associated with low level infections with mycoplasma and other cell wall deficient bacteria $(138,139)$.

\section{Anterior Uveitis}

Increasingly, viral aetiologies have been identified for many cases of chronic, recurrent uveitis including rubella, VZV, CMV and HSV-1 and HSV-2. Patients recovering from Ebola and Zika virus infection develop recurrent/chronic anterior uveitis (see above section on viruses). M. tuberculosis and sarcoidosis are known causes of granulomatous uveitis; while Mtb has not be definitively identified as the cause of sarcoidosis, the disease has been linked to atypical mycobacterial infection (140). On a different note, HLA B27-associated acute anterior uveitis is associated with a disturbed microbiome in which translocating gut commensals have been incriminated $(141,142)$.

\section{Retinitis}

Retinitis can be caused by all classes of microorganism described above. However, the AIDS epidemic brought viral infections as a cause of retinitis to attention particularly CMV, HSV-1 and HSV-2 and VZV. Exposure to these viruses is widespread in the population (see above section on viruses). Initial infection occurs early in life and latent infection is controlled by the immune system for the lifetime of the host. CMV resides in myeloid cells in the uveal tract and can pass to RPE cells by direct spread. $\mathrm{CD} 8+\mathrm{T}$ cells control latent virus which replicates slowly and spreads contiguously in a brush-fire or patchy fashion when CD4/CD8 T cell immunity is impaired (143).

\section{Choroiditis}

Choroiditis as a discrete entity is uncommon and takes several clinical forms including multifocal choroiditis and serpiginous choroiditis. Tuberculosis is strongly implicated in serpiginous disease (144) while several infectious aetiologies have been linked to cases of acute posterior multifocal placoid pigment epitheliopathy (APMPPE) (145-153).

\section{ARE MOST FORMS OF INTRAOCULAR INFLAMMATION INFECTIOUS?}

Although in developed countries, a microbial aetiology for noninfectious uveitis is often elusive, the door to an infectious aetiology has been left open by the re-branding of "noninfectious" IOI to "undifferentiated" IOI (38). In effect, this terminology admits that cases of IOI/uveitis, in which a microbial aetiology cannot be identified, also cannot be differentiated clinically from cases of infectious IOI, and despite the range of clinical presentations the commonality between infectious and "non-infectious" is striking.

As detailed above, pathogenetically, infectious agents initiate disease by entry across mucosal or skin barriers in which the primary infection may or may not be symptomatic. If the initial infection is not completely cleared, in line with the DRF concepts, it is likely that one of the five potential outcomes of this initial interaction occurs: infection, colonisation, commensalism, disease and latency. Both disease and latency outcomes require systemic microbial dissemination and localisation to the target site. For many of the clinical conditions described above, reactivation from latent infection is the most likely pathogenetic explanation since latency is a function of both the CNS microenvironment and a robust immune response. It is this immune response which promotes latency via both $\mathrm{CD} 4+$ and $\mathrm{CD} 8+\mathrm{T}$ cell activity for the lifetime of the host. Only when immunity declines (immunosuppression, AIDS, aging) does the latent microbe reactivate and replicate causing, in the case of the eye, 


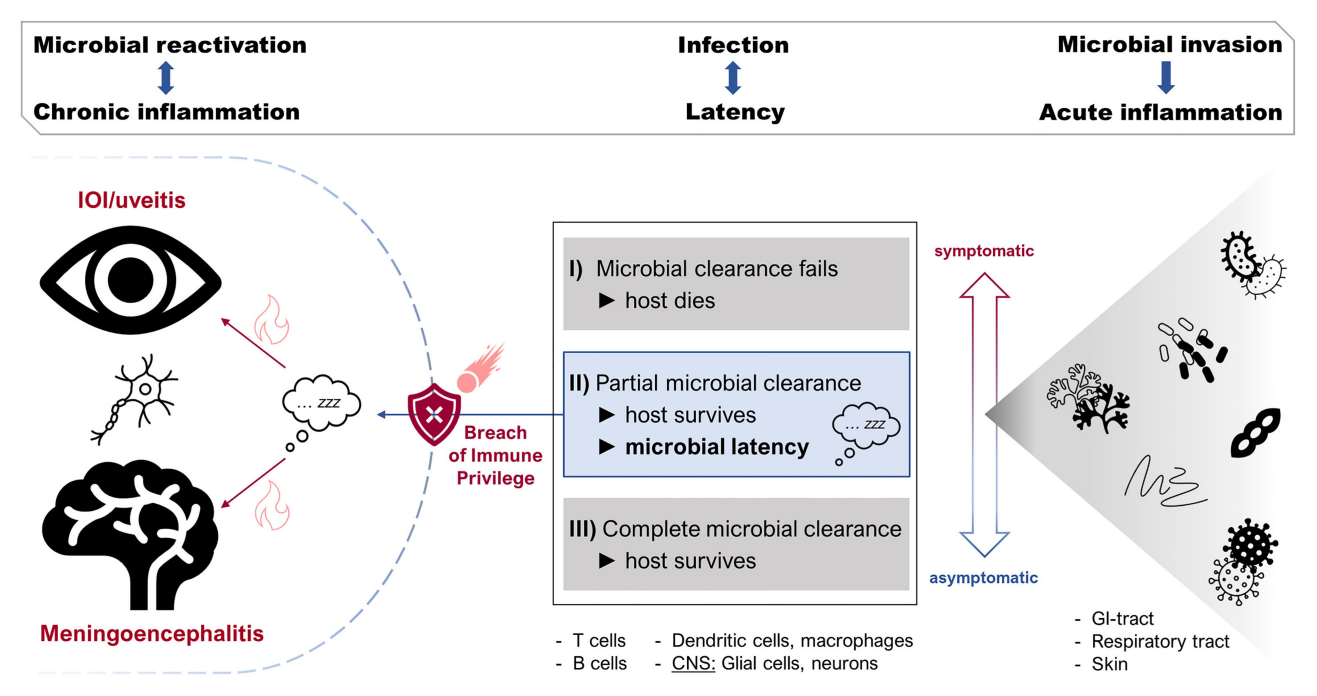

FIGURE 2 | Host microbe interaction: the precarious relationship between immune privilege (IP) and latent infection. Microbial challenge and invasion of the host through external barriers (cartoon on right) causes acute inflammation and spread of infection with one of three outcomes (box in centre). The host survives if the infection is fully cleared or if the infection becomes latent. Keeping microbes in a latent state depends not only on a conducive ("privileged") microenvironment such as that in the CNS but on a sustained immune response. The microbe can reactivate when IP is breached by immune dysregulation (cartoon on left).

devastating IOI. We argue therefore that most if not all cases of IOI are caused by, and are the consequence of, a host-microbe interaction and the nature of tissue damage varies dependent upon whether the microbe is replicating and causing direct tissue necrosis (e.g. CMV retinitis) or whether there is an exaggerated immune reaction to the pathogen as occurs in reactivated Ebola and Mtb latent uveitis.

\section{CONCLUSION}

The CNS acts as a preferred site for latent infections, not only through its complement of stable, quiescent structural cells, its physico-chemical and its immunological barriers, but also in providing a microenvironment where immune cells can reside in a "housekeeping", homeostatic role i.e. the meninges and the uveal tract. This allows parasitic, bacterial, fungal and viral infections, disseminating from sites of infection elsewhere, to set up home as latent infections within immune cells (T cells, B cells, and macrophages, dendritic cells, and microglial cells) as well as parenchymal cells, which act as safe havens for microbes to evade the immune system (154) (Figure 2).

Inflammation generally is now considered to be an integral part of many diseases, previously considered to be genetic, metabolic, or degenerative (155). The driver for this "physiological" inflammation is likely to be microbial and related to the microbiome since the microbiome is central to the development of both the innate and the adaptive immune response (156). Certain unconventional $\mathrm{T}$ cells in the gut and elsewhere (iNKT cells, $\gamma \delta$ cells and MAIT cells) imprinted in neonatal life are critical for tissue homeostasis (157) and many of the infections discussed here are contracted in early childhood.
When the system is perturbed as occurs on pathogen challenge, the organism acts to clear the pathogen and restore homeostasis, achieved through inflammation (17). This may be completely silent (asymptomatic infection) or life-threatening, but if the host survives, its clearance of the pathogen is unlikely to be complete, and persistent (latent) pathogens in the host continue to drive the homeostatic (immunogenic) response. At times, this may take the form of overt inflammation (IOI) or may be silent, and the eye is an especially sensitive sensor of this response as for instance with the "pepper-and-salt" pigmentary retinopathy of congenital rubella or childhood giardiasis. It is no surprise therefore that "undifferentiated" IOI is similar to infectious IOI and, whether the pathogen is detectable or not, it is a sobering thought that many of us, having been exposed to these pathogens, continue to harbour them within our cells and tissues in apparent good health until, that is, our immune systems let us down.

\section{AUTHOR CONTRIBUTIONS}

JVF conceptualised and wrote the article. CM created figures. LK provided images. All authors critically revised and edited the manuscript and provided expert input. All authors contributed to the article and approved the submitted version.

\section{FUNDING}

University of Aberdeen Development Trust/Saving Sight in Grampian: grant number RG16220-10 


\section{REFERENCES}

1. Matzinger P, Kamala T. Tissue-Based Class Control: The Other Side of Tolerance. Nat Rev Immunol (2011) 11(3):221-30. doi: 10.1038/nri2940

2. Hwang S, Cobb DA, Bhadra R, Youngblood B, Khan IA. Blimp-1-Mediated CD4 T Cell Exhaustion Causes CD8 T Cell Dysfunction During Chronic Toxoplasmosis. J Exp Med (2016) 213(9):1799-818. doi: 10.1084/ jem.20151995

3. Davids M, Pooran AS, Pietersen E, Wainwright HC, Binder A, Warren R, et al. Regulatory T Cells Subvert Mycobacterial Containment in Patients Failing Extensively Drug-Resistant Tuberculosis Treatment. Am J Respir Crit Care Med (2018) 198(1):104-16. doi: 10.1164/rccm.201707-1441OC

4. Peters N, Sacks D. Immune Privilege in Sites of Chronic Infection: Leishmania and Regulatory T Cells. Immunol Rev (2006) 213:159-79. doi: 10.1111/j.1600-065X.2006.00432.x

5. Molzer C, Heissigerova J, Wilson HM, Kuffova L, Forrester JV. Immune Privilege: The Microbiome and Uveitis. Front Immunol (2020) 11:608377. doi: $10.3389 /$ fimmu.2020.608377

6. Medawar PB. Immunological Tolerance. Nature (1961) 189:14-7. doi: $10.1038 / 189014 \mathrm{a} 0$

7. Sakaguchi S, Mikami N, Wing JB, Tanaka A, Ichiyama K, Ohkura N. Regulatory T Cells and Human Disease. Annu Rev Immunol (2020) 38:54166. doi: 10.1146/annurev-immunol-042718-041717

8. Kyewski B, Klein L. A Central Role for Central Tolerance. Annu Rev Immunol (2006) 24:571-606. doi: 10.1146/annurev.immunol.23.021704. 115601

9. Medawar PB. Immunity to Homologous Grafted Skin; the Fate of Skin Homografts Transplanted to the Brain, to Subcutaneous Tissue, and to the Anterior Chamber of the Eye. Br J Exp Pathol (1948) 29(1):58-69.

10. Forrester JV, McMenamin PG, Dando SJ. CNS Infection and Immune Privilege. Nat Rev Neurosci (2018) 19(11):655-71. doi: 10.1038/s41583018-0070-8

11. Huber AK, Duncker PC, Irani DN. Immune Responses to Non-Tumor Antigens in the Central Nervous System. Front Oncol (2014) 4:328. doi: $10.3389 /$ fonc. 2014.00328

12. Huber AK, Irani DN. Is the Concept of Central Nervous System Immune Privilege Irrelevant in the Setting of Acute Infection? Front Oncol (2015) 5:99. doi: 10.3389/fonc.2015.00099

13. Solomos AC, Rall G. Get It Through Your Thick Head: Emerging Principles in Neuroimmunology and Neurovirology Redefine Central Nervous System "Immune Privilege". ACS Chem Neurosci (2016) 7(4):435-41. doi: 10.1021/ acschemneuro. $5 \mathrm{~b} 00336$

14. Janeway CAJr., Medzhitov R. Innate Immune Recognition. Annu Rev Immunol (2002) 20:197-216. doi: 10.1146/annurev.immunol.20.083001. 084359

15. Steinman RM. Decisions About Dendritic Cells: Past, Present, and Future. Annu Rev Immunol (2012) 30:1-22. doi: 10.1146/annurev-immunol100311-102839

16. Matzinger P. Tolerance, Danger, and the Extended Family. Annu Rev Immunol (1994) 12:991-1045. doi: 10.1146/annurev.iy.12.040194.005015

17. Meizlish ML, Franklin RA, Zhou X, Medzhitov R. Tissue Homeostasis and Inflammation. Annu Rev Immunol (2021) 39:557-81. doi: 10.1146/annurevimmunol-061020-053734

18. Casadevall A, Pirofski LA. The Damage-Response Framework of Microbial Pathogenesis. Nat Rev Microbiol (2003) 1(1):17-24. doi: 10.1038/ nrmicro732

19. Ferguson TA, Griffith TS. The Role of Fas Ligand and TNF-Related Apoptosis-Inducing Ligand (TRAIL) in the Ocular Immune Response. Chem Immunol Allergy (2007) 92:140-54. doi: 10.1159/000099265

20. Proekt I, Miller CN, Jeanne M, Fasano KJ, Moon JJ, Lowell CA, et al. LYNand AIRE-Mediated Tolerance Checkpoint Defects Synergize to Trigger Organ-Specific Autoimmunity. J Clin Invest (2016) 126(10):3758-71. doi: $10.1172 /$ JCI 84440

21. Taylor AW, Ng TF. Negative Regulators That Mediate Ocular Immune Privilege. J Leukoc Biol (2018) 103:1179-87. doi: 10.1002/JLB.3MIR0817$337 \mathrm{R}$

22. Mochizuki M, Sugita S, Kamoi K. Immunological Homeostasis of the Eye. Prog Retin Eye Res (2013) 33:10-27. doi: 10.1016/j.preteyeres.2012.10.002
23. Liu YH, Molzer C, Makinen K, Kamoi K, Corbett CLC, Klaska IP, et al. Treatment With FoxP3+ Antigen-Experienced T Regulatory Cells Arrests Progressive Retinal Damage in a Spontaneous Model of Uveitis. Front Immunol (2020) 11:2071. doi: 10.3389/fimmu.2020.02071

24. Pletinckx K, Vaeth M, Schneider T, Beyersdorf N, Hunig T, BerberichSiebelt F, et al. Immature Dendritic Cells Convert Anergic Nonregulatory T Cells Into Foxp3- IL-10+ Regulatory T Cells by Engaging CD28 and CTLA4. Eur J Immunol (2015) 45(2):480-91. doi: 10.1002/eji.201444991

25. Molzer C, Wilson HM, Kuffova L, Forrester JV. A Role for Folate in Microbiome-Linked Control of Autoimmunity. J Immunol Res (2021) 2021:9998200. doi: 10.1155/2021/9998200

26. Choi JK, Egwuagu CE. Analysis of Regulatory B Cells in Experimental Autoimmune Uveitis. Methods Mol Biol (2021) 2270:437-50. doi: 10.1007/ 978-1-0716-1237-8_23

27. Keino H, Horie S, Sugita S. Immune Privilege and Eye-Derived T-Regulatory Cells. J Immunol Res (2018) 2018:1679197. doi: 10.1155/2018/1679197

28. Pleyer U, Neri P, Deuter C. New Pharmacotherapy Options for Noninfectious Posterior Uveitis. Int Ophthalmol (2021) 41(6):2265-81. doi: 10.1007/s10792-021-01763-8

29. Guex-Crosier Y, Auer C, Bernasconi O, Herbort CP. Toxoplasmic Retinochoroiditis: Resolution Without Treatment of the Perilesional Satellite Dark Dots Seen by Indocyanine Green Angiography. Graefes Arch Clin Exp Ophthalmol (1998) 236(6):476-8. doi: 10.1007/s004170050108

30. Lin P. Infectious Uveitis. Curr Ophthalmol Rep (2015) 3(3):170-83. doi: 10.1007/s40135-015-0076-6

31. Gerada C, Campbell TM, Kennedy JJ, McSharry BP, Steain M, Slobedman B, et al. Manipulation of the Innate Immune Response by Varicella Zoster Virus. Front Immunol (2020) 11:1. doi: 10.3389/fimmu.2020.00001

32. Chen X, Yu H, Mei T, Chen B, Chen L, Li S, et al. SARS-CoV-2 on the Ocular Surface: Is It Truly a Novel Transmission Route? Br J Ophthalmol (2021) 105 (9):1190-5. doi: 10.1136/bjophthalmol-2020-316263

33. Whitmer SLM, Ladner JT, Wiley MR, Patel K, Dudas G, Rambaut A, et al. Active Ebola Virus Replication and Heterogeneous Evolutionary Rates in EVD Survivors. Cell Rep (2018) 22(5):1159-68. doi: 10.1016/ j.celrep.2018.01.008

34. Eghrari AO, Shantha JG, Ross RD, Ryn CV, Crozier I, Hayek B, et al. Efficacy and Safety Outcomes of Cataract Surgery in Survivors of Ebola Virus Disease: 12-Month Results From the PREVAIL VII Study. Transl Vis Sci Technol (2021) 10(1):32. doi: 10.1167/tvst.10.1.32

35. Couderc T, Gangneux N, Chretien F, Caro V, Le Luong T, Ducloux B, et al. Chikungunya Virus Infection of Corneal Grafts. J Infect Dis (2012) 206 (6):851-9. doi: 10.1093/infdis/jis296

36. Qu JH, Peng RM, Xiao GG, Qu HQ, Yu T, Zhang S, et al. The Incidence and Influence of the Donor Corneas Positive for Herpesviridae DNA in Keratoplasty. Graefes Arch Clin Exp Ophthalmol (2020) 258(12):2767-74. doi: 10.1007/s00417-020-04984-2

37. Maddox RA, Belay ED, Curns AT, Zou WQ, Nowicki S, Lembach RG, et al. Creutzfeldt-Jakob Disease in Recipients of Corneal Transplants. Cornea (2008) 27(7):851-4. doi: 10.1097/ICO.0b013e31816a628d

38. Standardization of Uveitis Nomenclature Working G. Development of Classification Criteria for the Uveitides. Am J Ophthalmol (2021) 228:96105. doi: 10.1016/j.ajo.2021.03.061

39. Jabs DA, Nussenblatt RB, Rosenbaum JT. Standardization of Uveitis Nomenclature Working G. Standardization of Uveitis Nomenclature for Reporting Clinical Data. Results of the First International Workshop. Am J Ophthalmol (2005) 140(3):509-16. doi: 10.1016/j.ajo.2005.03.057

40. Caspi RR. Ocular Autoimmunity: The Price of Privilege? Immunol Rev (2006) 213:23-35. doi: 10.1111/j.1600-065X.2006.00439.x

41. Forrester JV, Xu H. Good News-Bad News: The Yin and Yang of Immune Privilege in the Eye. Front Immunol (2012) 3:338. doi: 10.3389/fimmu.2012.00338

42. Galea I, Bechmann I, Perry VH. What Is Immune Privilege (Not)? Trends Immunol (2007) 28(1):12-8. doi: 10.1016/j.it.2006.11.004

43. Streilein JW. Ocular Immune Privilege: Therapeutic Opportunities From an Experiment of Nature. Nat Rev Immunol (2003) 3(11):879-89. doi: 10.1038/ nri1224

44. Lepisto AJ, Frank GM, Hendricks RL. How Herpes Simplex Virus Type 1 Rescinds Corneal Privilege. Chem Immunol Allergy (2007) 92:203-12. doi: $10.1159 / 000099271$ 
45. Pirofski LA, Casadevall A. The State of Latency in Microbial Pathogenesis. J Clin Invest (2020) 130(9):4525-31. doi: 10.1172/JCI136221

46. Brunet K, Alanio A, Lortholary O, Rammaert B. Reactivation of Dormant/ Latent Fungal Infection. J Infect (2018) 77(6):463-8. doi: 10.1016/ j.jinf.2018.06.016

47. Cain MD, Salimi H, Diamond MS, Klein RS. Mechanisms of Pathogen Invasion Into the Central Nervous System. Neuron (2019) 103(5):771-83. doi: 10.1016/j.neuron.2019.07.015

48. Normile TG, Bryan AM, Del Poeta M. Animal Models of Cryptococcus Neoformans in Identifying Immune Parameters Associated With Primary Infection and Reactivation of Latent Infection. Front Immunol (2020) 11:581750. doi: 10.3389/fimmu.2020.581750

49. Decote-Ricardo D, LaRocque-de-Freitas IF, Rocha JDB, Nascimento DO, Nunes MP, Morrot A, et al. Immunomodulatory Role of Capsular Polysaccharides Constituents of Cryptococcus Neoformans. Front Med (Lausanne) (2019) 6:129. doi: 10.3389/fmed.2019.00129

50. Denham ST, Verma S, Reynolds RC, Worne CL, Daugherty JM, Lane TE, et al. Regulated Release of Cryptococcal Polysaccharide Drives Virulence and Suppresses Immune Cell Infiltration Into the Central Nervous System. Infect Immun (2018) 86(3):e00662-17. doi: 10.1128/IAI.00662-17

51. Snarr BD, Drummond RA, Lionakis MS. It's All in Your Head: Antifungal Immunity in the Brain. Curr Opin Microbiol (2020) 58:41-6. doi: 10.1016/ j.mib.2020.07.011

52. Arastehfar A, Carvalho A, Houbraken J, Lombardi L, Garcia-Rubio R, Jenks JD, et al. Aspergillus Fumigatus and Aspergillosis: From Basics to Clinics. Stud Mycol (2021) 100:100115. doi: 10.1016/j.simyco.2021.100115

53. Carare RO, Hawkes CA, Weller RO. Afferent and Efferent Immunological Pathways of the Brain. Anatomy Funct Failure Brain Behav Immun (2014) 36:9-14. doi: 10.1016/j.bbi.2013.10.012

54. Jarolim KL, McCosh JK, Howard MJ, John DT. A Light Microscopy Study of the Migration of Naegleria Fowleri From the Nasal Submucosa to the Central Nervous System During the Early Stage of Primary Amebic Meningoencephalitis in Mice. J Parasitol (2000) 86(1):50-5. doi: 10.1645/ 0022-3395(2000)086[0050:ALMSOT]2.0.CO;2

55. Shih RY, Koeller KK. Bacterial, Fungal, and Parasitic Infections of the Central Nervous System: Radiologic-Pathologic Correlation and Historical Perspectives. Radiographics (2015) 35(4):1141-69. doi: 10.1148/rg.2015140317

56. St John JA, Ekberg JA, Dando SJ, Meedeniya AC, Horton RE, Batzloff M, et al. Burkholderia Pseudomallei Penetrates the Brain via Destruction of the Olfactory and Trigeminal Nerves: Implications for the Pathogenesis of Neurological Melioidosis. MBio (2014) 5(2):e00025. doi: 10.1128/ mBio.00025-14

57. Gupta A, Hustler A, Herieka E, Matthews BN. Pneumocystis Choroiditis. Eye (Lond) (2010) 24(1):178. doi: 10.1038/eye.2009.52

58. Meyer D. Eye Signs That Alert the Clinician to a Diagnosis of AIDS. SADJ (2005) 60(9):386-7.

59. Dubey JP. Outbreaks of Clinical Toxoplasmosis in Humans: Five Decades of Personal Experience, Perspectives and Lessons Learned. Parasit Vectors (2021) 14(1):263. doi: 10.1186/s13071-021-04769-4

60. Johnson SK, Johnson PTJ. Toxoplasmosis: Recent Advances in Understanding the Link Between Infection and Host Behavior. Annu Rev Anim Biosci (2021) 9:249-64. doi: 10.1146/annurev-animal-081720-111125

61. Madireddy S, Rivas Chacon ED, Mangat R. Toxoplasmosis. Treasure Island, FL: StatPearls (2022).

62. Weidner JM, Kanatani S, Uchtenhagen H, Varas-Godoy M, Schulte T, Engelberg K, et al. Migratory Activation of Parasitized Dendritic Cells by the Protozoan Toxoplasma Gondii 14-3-3 Protein. Cell Microbiol (2016) 18 (11):1537-50. doi: $10.1111 / \mathrm{cmi} .12595$

63. Watts E, Zhao Y, Dhara A, Eller B, Patwardhan A, Sinai AP. Novel Approaches Reveal That Toxoplasma Gondii Bradyzoites Within Tissue Cysts Are Dynamic and Replicating Entities In Vivo. mBio (2015) 6(5): e01155-15. doi: 10.1128/mBio.01155-15

64. Khan IA, Ouellette C, Chen K, Moretto M. Toxoplasma: Immunity and Pathogenesis. Curr Clin Microbiol Rep (2019) 6(1):44-50. doi: 10.1007/ s40588-019-0114-5

65. Tsitsiklis A, Bangs DJ, Robey EA. CD8(+) T Cell Responses to Toxoplasma Gondii: Lessons From a Successful Parasite. Trends Parasitol (2019) 35 (11):887-98. doi: 10.1016/j.pt.2019.08.005
66. Still KM, Batista SJ, O’Brien CA, Oyesola OO, Fruh SP, Webb LM, et al. Astrocytes Promote a Protective Immune Response to Brain Toxoplasma Gondii Infection via IL-33-ST2 Signaling. PloS Pathog (2020) 16(10): e1009027. doi: 10.1371/journal.ppat.1009027

67. Salvioni A, Belloy M, Lebourg A, Bassot E, Cantaloube-Ferrieu V, Vasseur V, et al. Robust Control of a Brain-Persisting Parasite Through MHC I Presentation by Infected Neurons. Cell Rep (2019) 27(11):3254-68.e8. doi: 10.1016/j.celrep.2019.05.051

68. Tong X, Lu F. IL-33/ST2 Involves the Immunopathology of Ocular Toxoplasmosis in Murine Model. Parasitol Res (2015) 114(5):1897-905. doi: 10.1007/s00436-015-4377-3

69. Batista SJ, Still KM, Johanson D, Thompson JA, O’Brien CA, Lukens JR, et al. Gasdermin-D-Dependent IL-1alpha Release From Microglia Promotes Protective Immunity During Chronic Toxoplasma Gondii Infection. Nat Commun (2020) 11(1):3687. doi: 10.1038/s41467-020-17491-z

70. Halliez MC, Buret AG. Extra-Intestinal and Long Term Consequences of Giardia Duodenalis Infections. World J Gastroenterol (2013) 19(47):897485. doi: 10.3748/wjg.v19.i47.8974

71. Corsi A, Nucci C, Knafelz D, Bulgarini D, Di Iorio L, Polito A, et al. Ocular Changes Associated With Giardia Lamblia Infection in Children. $\mathrm{Br} J$ Ophthalmol (1998) 82(1):59-62. doi: 10.1136/bjo.82.1.59

72. Pettoello Mantovani M, Giardino I, Magli A, di Martino L, Guandalini S. Intestinal Giardiasis Associated With Ophthalmologic Changes. J Pediatr Gastroenterol Nutr (1990) 11(2):196-200. doi: 10.1097/00005176199008000-00007

73. Izadi M, Pourazizi M, Babaei M, Saffaei A, Alemzadeh-Ansari MH. Ocular Parasitosis Caused by Protozoan Infection During Travel: Focus on Prevention and Treatment. Int J Prev Med (2018) 9:79. doi: 10.4103/ ijpvm.IJPVM_161_18

74. Whittaker C, Walker M, Pion SDS, Chesnais CB, Boussinesq M, Basanez MG. The Population Biology and Transmission Dynamics of Loa Loa. Trends Parasitol (2018) 34(4):335-50. doi: 10.1016/j.pt.2017.12.003

75. Mazzeo T, Dos Santos Motta MM, Curi ALL. Diffuse Unilateral Subacute Neuroretinitis: Review Article. J Ophthal Inflamm Infect (2019) 9(1):23. doi: 10.1186/s12348-019-0191-x

76. Sadeghipour S, Mathias RA. Herpesviruses Hijack Host Exosomes for Viral Pathogenesis. Semin Cell Dev Biol (2017) 67:91-100. doi: 10.1016/ j.semcdb.2017.03.005

77. Shnayder M, Nachshon A, Rozman B, Bernshtein B, Lavi M, Fein N, et al. Single Cell Analysis Reveals Human Cytomegalovirus Drives Latently Infected Cells Towards an Anergic-Like Monocyte State. Elife (2020) 9: e52168. doi: 10.7554/eLife.52168

78. Zhu D, Pan C, Sheng J, Liang H, Bian Z, Liu Y, et al. Human Cytomegalovirus Reprogrammes Haematopoietic Progenitor Cells Into Immunosuppressive Monocytes to Achieve Latency. Nat Microbiol (2018) 3(4):503-13. doi: 10.1038/s41564-018-0131-9

79. Rowe AM, St Leger AJ, Jeon S, Dhaliwal DK, Knickelbein JE, Hendricks RL. Herpes Keratitis. Prog Retin Eye Res (2013) 32:88-101. doi: 10.1016/ j.preteyeres.2012.08.002

80. Hassani A, Corboy JR, Al-Salam S, Khan G. Epstein-Barr Virus Is Present in the Brain of Most Cases of Multiple Sclerosis and May Engage More Than Just B Cells. PloS One (2018) 13(2):e0192109. doi: 10.1371/journal.pone.0192109

81. Geginat J, Paroni M, Pagani M, Galimberti D, De Francesco R, Scarpini E, et al. The Enigmatic Role of Viruses in Multiple Sclerosis: Molecular Mimicry or Disturbed Immune Surveillance? Trends Immunol (2017) 38 (7):498-512. doi: 10.1016/j.it.2017.04.006

82. Lunemann JD, Munz C. EBV in MS: Guilty by Association? Trends Immunol (2009) 30(6):243-8. doi: 10.1016/j.it.2009.03.007

83. Kuri A, Jacobs BM, Vickaryous N, Pakpoor J, Middeldorp J, Giovannoni G, et al. Epidemiology of Epstein-Barr Virus Infection and Infectious Mononucleosis in the United Kingdom. BMC Public Health (2020) 20 (1):912. doi: 10.1186/s12889-020-09049-x

84. Bjornevik K, Cortese M, Healy BC, Kuhle J, Mina MJ, Leng Y, et al. Longitudinal Analysis Reveals High Prevalence of Epstein-Barr Virus Associated With Multiple Sclerosis. Science (2022) 375(6578):296-301. doi: $10.1126 /$ science.abj8222

85. Robinson WH, Steinman L. Epstein-Barr Virus and Multiple Sclerosis. Science (2022) 375:eabm7930. doi: 10.1126/science.abm7930 
86. Tengvall K, Huang J, Hellstrom C, Kammer P, Bistrom M, Ayoglu B, et al. Molecular Mimicry Between Anoctamin 2 and Epstein-Barr Virus Nuclear Antigen 1 Associates With Multiple Sclerosis Risk. Proc Natl Acad Sci USA (2019) 116(34):16955-60. doi: 10.1073/pnas.1902623116

87. Serafini B, Rosicarelli B, Veroni C, Mazzola GA, Aloisi F. Epstein-Barr Virus-Specific CD8 T Cells Selectively Infiltrate the Brain in Multiple Sclerosis and Interact Locally With Virus-Infected Cells: Clue for a VirusDriven Immunopathological Mechanism. J Virol (2019) 93(24):e00980-19. doi: 10.1128/JVI.00980-19

88. Serafini B, Scorsi E, Rosicarelli B, Rigau V, Thouvenot E, Aloisi F. Massive Intracerebral Epstein-Barr Virus Reactivation in Lethal Multiple Sclerosis Relapse After Natalizumab Withdrawal. J Neuroimmunol (2017) 307:14-7. doi: 10.1016/j.jneuroim.2017.03.013

89. Magliozzi R, Serafini B, Rosicarelli B, Chiappetta G, Veroni C, Reynolds R, et al. B-Cell Enrichment and Epstein-Barr Virus Infection in Inflammatory Cortical Lesions in Secondary Progressive Multiple Sclerosis. J Neuropathol Exp Neurol (2013) 72(1):29-41. doi: 10.1097/NEN.0b013e31827bfc62

90. Lin J, Chen RWS, Hazan A, Weiss M. Chikungunya Virus Infection Manifesting as Intermediate Uveitis. Ocul Immunol Inflamm (2018) 26 (5):680-2. doi: 10.1080/09273948.2016.1263340

91. Lee JY, Bowden DS. Rubella Virus Replication and Links to Teratogenicity. Clin Microbiol Rev (2000) 13(4):571-87. doi: 10.1128/CMR.13.4.571

92. Singh S, Kumar A. Ocular Manifestations of Emerging Flaviviruses and the Blood-Retinal Barrier. Viruses (2018) 10(10):530. doi: 10.3390/v10100530

93. Nelson AN, Lin WW, Shivakoti R, Putnam NE, Mangus L, Adams RJ, et al. Association of Persistent Wild-Type Measles Virus RNA With Long-Term Humoral Immunity in Rhesus Macaques. JCI Insight (2020) 5(3):e134992. doi: $10.1172 /$ jci.insight.134992

94. Ireland DDC, Manangeeswaran M, Lewkowicz AP, Engel K, Clark SM, Laniyan A, et al. Long-Term Persistence of Infectious Zika Virus: Inflammation and Behavioral Sequela in Mice. PloS Pathog (2020) 16(12): e1008689. doi: 10.1371/journal.ppat.1008689

95. Yeh S, Shantha JG, Hayek B, Crozier I, Smith JR. Clinical Manifestations and Pathogenesis of Uveitis in Ebola Virus Disease Survivors. Ocul Immunol Inflamm (2018) 26:7:1-7. doi: 10.1080/09273948.2018.1484493

96. Smith JR, Todd S, Ashander LM, Charitou T, Ma Y, Yeh S, et al. Retinal Pigment Epithelial Cells Are a Potential Reservoir for Ebola Virus in the Human Eye. Transl Vis Sci Technol (2017) 6(4):12. doi: 10.1167/ tvst.6.4.12

97. Mbala-Kingebeni P, Pratt C, Mutafali-Ruffin M, Pauthner MG, Bile F, Nkuba-Ndaye A, et al. Ebola Virus Transmission Initiated by Relapse of Systemic Ebola Virus Disease. N Engl J Med (2021) 384(13):1240-7. doi: 10.1056/NEJMoa2024670

98. McArthur JC, Johnson TP. Chronic Inflammation Mediates Brain Injury in HIV Infection: Relevance for Cure Strategies. Curr Opin Neurol (2020) 33 (3):397-404. doi: 10.1097/WCO.0000000000000807

99. Chan P, Ananworanich J. Perspective on Potential Impact of HIV Central Nervous System Latency on Eradication. AIDS (2019) 33 (Suppl 2):S123S33. doi: 10.1097/QAD.0000000000002264

100. Kamoi K. HTLV-1 in Ophthalmology. Front Microbiol (2020) 11:388. doi: 10.3389/fmicb.2020.00388

101. Terada Y, Kamoi K, Komizo T, Miyata K, Mochizuki M. Human T Cell Leukemia Virus Type 1 and Eye Diseases. J Ocul Pharmacol Ther (2017) 33 (4):216-23. doi: 10.1089/jop.2016.0124

102. Trajkovic V, Vuckovic O, Stosic-Grujicic S, Miljkovic D, Popadic D, Markovic M, et al. Astrocyte-Induced Regulatory T Cells Mitigate CNS Autoimmunity. Glia (2004) 47(2):168-79. doi: 10.1002/glia.20046

103. Hong W, Cheng W, Zheng T, Jiang N, Xu R. AHR Is a Tunable Knob That Controls HTLV-1 Latency-Reactivation Switching. PloS Pathog (2020) 16(7): e1008664. doi: 10.1371/journal.ppat.1008664

104. Yan F, He J, Tang L, Kong Y, Shi Y, Chen S, et al. Transforming Growth Factor-Beta2 Increases the Capacity of Retinal Pigment Epithelial Cells to Induce the Generation of Regulatory T Cells. Mol Med Rep (2016) 13 (2):1367-72. doi: 10.3892/mmr.2015.4666

105. Chen X, Liu L, Yang P, Wu C, Jin H, Xing L, et al. Indoleamine 2,3Dioxygenase (IDO) Is Involved in Promoting the Development of Anterior Chamber-Associated Immune Deviation. Immunol Lett (2006) 107(2):1407. doi: 10.1016/j.imlet.2006.08.006
106. Hirons A, Khoury G, Purcell DFJ. Human T-Cell Lymphotropic Virus Type1: A Lifelong Persistent Infection, Yet Never Truly Silent. Lancet Infect Dis (2021) 21(1):e2-e10. doi: 10.1016/S1473-3099(20)30328-5

107. Mehta SK, Laudenslager ML, Stowe RP, Crucian BE, Sams CF, Pierson DL. Multiple Latent Viruses Reactivate in Astronauts During Space Shuttle Missions. Brain Behav Immun (2014) 41:210-7. doi: 10.1016/j.bbi.2014.05.014

108. Ganchua SKC, White AG, Klein EC, Flynn JL. Lymph Nodes-The Neglected Battlefield in Tuberculosis. PloS Pathog (2020) 16(8):e1008632. doi: 10.1371/ journal.ppat.1008632

109. Sundararajan S, Muniyan R. Latent Tuberculosis: Interaction of Virulence Factors in Mycobacterium Tuberculosis. Mol Biol Rep (2021) 48(8):6181-96. doi: 10.1007/s11033-021-06611-7

110. Xu W, Snell LM, Guo M, Boukhaled G, Macleod BL, Li M, et al. Early Innate and Adaptive Immune Perturbations Determine Long-Term Severity of Chronic Virus and Mycobacterium Tuberculosis Coinfection. Immunity (2021) 54(3):526-41.e7. doi: 10.1016/j.immuni.2021.01.003

111. Elkington P, Polak ME, Reichmann MT, Leslie A. Understanding the Tuberculosis Granuloma: The Matrix Revolutions. Trends Mol Med (2021) 28(2):143-54. doi: 10.1016/j.molmed.2021.11.004

112. Benet S, Galvez C, Drobniewski F, Kontsevaya I, Arias L, Monguio-Tortajada $\mathrm{M}$, et al. Dissemination of Mycobacterium Tuberculosis Is Associated to a SIGLEC1 Null Variant That Limits Antigen Exchange via Trafficking Extracellular Vesicles. J Extracell Vesicles (2021) 10(3):e12046. doi: 10.1002/jev2.12046

113. Salgame P, Geadas C, Collins L, Jones-Lopez E, Ellner JJ. Latent Tuberculosis Infection-Revisiting and Revising Concepts. Tuberculosis (Edinb) (2015) 95 (4):373-84. doi: 10.1016/j.tube.2015.04.003

114. Boom WH, Schaible UE, Achkar JM. The Knowns and Unknowns of Latent Mycobacterium Tuberculosis Infection. J Clin Invest (2021) 131(3):e136222. doi: $10.1172 /$ JCI136222

115. Peeling RW, Mabey D, Kamb ML, Chen XS, Radolf JD, Benzaken AS. Syphilis. Nat Rev Dis Primers (2017) 3:17073. doi: 10.1038/nrdp.2017.73

116. Gonzalez H, Koralnik IJ, Marra CM. Neurosyphilis. Semin Neurol (2019) 39 (4):448-55. doi: 10.1055/s-0039-1688942

117. Berger JR, Dean D. Neurosyphilis. Handb Clin Neurol (2014) 121:1461-72. doi: 10.1016/B978-0-7020-4088-7.00098-5

118. Castro R, Aguas MJ, Batista T, Araujo C, Mansinho K, Pereira Fda L. Detection of Treponema Pallidum Sp. Pallidum DNA in Cerebrospinal Fluid (CSF) by Two PCR Techniques. J Clin Lab Anal (2016) 30(5):628-32. doi: 10.1002/jcla.21913

119. Hagihara M, Yamagishi Y, Kato H, Shibata Y, Shiota A, Sakanashi D, et al. Frequency of Treponema Pallidum Invasion Into Cerebrospinal Fluid in Primary or Secondary Early-Stage Syphilis. J Infect Chemother (2018) 24 (5):404-6. doi: 10.1016/j.jiac.2017.11.007

120. Pfister HW, Preac-Mursic V, Wilske B, Einhaupl KM, Weinberger K. Latent Lyme Neuroborreliosis: Presence of Borrelia Burgdorferi in the Cerebrospinal Fluid Without Concurrent Inflammatory Signs. Neurology (1989) 39(8):1118-20. doi: 10.1212/WNL.39.8.1118

121. Kawali A, Srinivasan S, Mahendradas P, Shetty B. Epidemic Retinitis and Community Outbreaks. Indian J Ophthalmol (2020) 68(9):1916-9. doi: 10.4103/ijo.IJO_1327_20

122. Portero A, Careno E, Real LA, Villaron S, Herreras JM. Infectious Nontuberculous Serpiginous Choroiditis. Arch Ophthalmol (2012) 130 (9):1207-8. doi: 10.1001/archophthalmol.2012.539

123. Johnson L, Wirostko E, Wirostko W, Rotterdam H. Mycoplasma-Like Organism Induced Murine Cardiac Microvasculopathy. A Transmission Electron Microscopic Study. Pathol Res Pract (1993) 189(4):448-52. doi: 10.1016/S0344-0338(11)80334-1

124. Wirostko E, Johnson L, Wirostko W. Chronic Intracellular Leucocytoclastic Bacterial Vitritis. A Transmission Electron Microscopic Study of the Monocytes. J Submicrosc Cytol Pathol (1988) 20(2):463-70.

125. Zhang Y, Amin S, Lung KI, Seabury S, Rao N, Toy BC. Incidence, Prevalence, and Risk Factors of Infectious Uveitis and Scleritis in the United States: A Claims-Based Analysis. PloS One (2020) 15(8):e0237995. doi: 10.1371/ journal.pone.0237995

126. Forrester JV, Kuffova L, Dick AD. Autoimmunity, Autoinflammation, and Infection in Uveitis. Am J Ophthalmol (2018) 189:77-85. doi: 10.1016/ j.ajo.2018.02.019 
127. Van Gelder RN. Molecular Diagnostics for Ocular Infectious Diseases: 78 (Th) Edward Jackson Memorial Lecture, American Academy of Ophthalmology. Am J Ophthalmol (2021) 235:300-12. doi: 10.1016/ j.ajo.2021.12.002

128. Parchand S, Tandan M, Gupta V, Gupta A. Intermediate Uveitis in Indian Population. J Ophthal Inflamm Infect (2011) 1(2):65-70. doi: 10.1007/ s12348-011-0020-3

129. Yim R, Posfay-Barbe KM, Nolt D, Fatula G, Wald ER. Spectrum of Clinical Manifestations of West Nile Virus Infection in Children. Pediatrics (2004) 114(6):1673-5. doi: 10.1542/peds.2004-0491

130. Kiss S, Letko E, Qamruddin S, Baltatzis S, Foster CS. Long-Term Progression, Prognosis, and Treatment of Patients With Recurrent Ocular Manifestations of Reiter's Syndrome. Ophthalmology (2003) 110(9):1764-9. doi: 10.1016/ S0161-6420(03)00620-1

131. Ormerod LD, Dailey JP. Ocular Manifestations of Cat-Scratch Disease. Curr Opin Ophthalmol (1999) 10(3):209-16. doi: 10.1097/00055735-19990600000010

132. Breeveld J, Rothova A, Kuiper H. Intermediate Uveitis and Lyme Borreliosis. Br J Ophthalmol (1992) 76(3):181-2. doi: 10.1136/bjo.76.3.181

133. Elliot AJ. 30-Year Observation of Patients With Eale's Disease. Am J Ophthalmol (1975) 80(3 Pt 1):404-8. doi: 10.1016/0002-9394(75)90525-5

134. Lopes BO, Brizido MS, Reis AI, Miranda MM, Pina SM. Eales' Disease: When the Rare Sounds Frequent. Case Rep Ophthalmol Med (2021) 2021:1056659. doi: 10.1155/2021/1056659

135. Agrawal R, Gunasekeran DV, Gonzalez-Lopez JJ, Cardoso J, Gupta B, Addison PK, et al. PERIPHERAL RETINAL VASCULITIS: Analysis of 110 Consecutive Cases and a Contemporary Reappraisal of Tubercular Etiology. Retina (2017) 37(1):112-7. doi: 10.1097/IAE.0000000000001239

136. van Langelaar J, Wierenga-Wolf AF, Samijn JPA, Luijks CJM, Siepman TA, van Doorn PA, et al. The Association of Epstein-Barr Virus Infection With CXCR3 (+) B-Cell Development in Multiple Sclerosis: Impact of Immunotherapies. Eur J Immunol (2021) 51(3):626-33. doi: 10.1002/eji.202048739

137. Tran VT, LeHoang P, Herbort CP. Value of High-Frequency Ultrasound Biomicroscopy in Uveitis. Eye (Lond) (2001) 15(Pt 1):23-30. doi: 10.1038/ eye. 2001.7

138. Wirostko E, Johnson L, Wirostko B. Ulcerative Colitis Associated Chronic Uveitis. Parasitization of Intraocular Leucocytes by Mollicute-Like Organisms. J Submicrosc Cytol Pathol (1990) 22(2):231-9.

139. Fox A. Role of Bacterial Debris in Inflammatory Diseases of the Joint and Eye. APMIS (1990) 98(11):957-68. doi: 10.1111/j.1699-0463.1990.tb05021.x

140. Reichmann MT, Tezera LB, Vallejo AF, Vukmirovic M, Xiao R, Reynolds J, et al. Integrated Transcriptomic Analysis of Human Tuberculosis Granulomas and a Biomimetic Model Identifies Therapeutic Targets. J Clin Invest (2021) 131(15):e148136. doi: 10.1172/JCI148136

141. Horai R, Caspi RR. Microbiome and Autoimmune Uveitis. Front Immunol (2019) 10:232. doi: 10.3389/fimmu.2019.00232

142. Rosenbaum JT, Asquith M. The Microbiome and HLA-B27-Associated Acute Anterior Uveitis. Nat Rev Rheumatol (2018) 14(12):704-13. doi: 10.1038/s41584-018-0097-2

143. Lee JH, Agarwal A, Mahendradas P, Lee CS, Gupta V, Pavesio CE, et al. Viral Posterior Uveitis. Surv Ophthalmol (2017) 62(4):404-45. doi: 10.1016/ j.survophthal.2016.12.008

144. Gupta V, Shoughy SS, Mahajan S, Khairallah M, Rosenbaum JT, Curi A, et al. Clinics of Ocular Tuberculosis. Ocul Immunol Inflamm (2015) 23(1):14-24. doi: 10.3109/09273948.2014.986582

145. Olguin-Manriquez F, Cernichiaro-Espinosa L, Olguin-Manriquez A, Manriquez-Arias R, Flores-Villalobos EO, Kawakami-Campos PA. Unilateral Acute Posterior Multifocal Placoid Pigment Epitheliopathy in a
Convalescent COVID-19 Patient. Int J Retina Vitreous (2021) 7(1):41. doi: 10.1186/s40942-021-00312-w

146. Cabral T, Mello LGM, Barcellos NN, Polido J, Pecanha PM, Saraiva FP, et al. Unilateral Acute Posterior Multifocal Placoid Pigment Epitheliopathy in a Patient With a Strongly Positive Purified Protein Derivative Test. Arq Bras Oftalmol (2019) 82(5):432-5. doi: 10.5935/0004-2749.20190084

147. Al Mousa M, Koch F. Acute Borrelia Infection Inducing an APMPPE-Like Picture. J Ophthal Inflamm Infect (2016) 6(1):22. doi: 10.1186/s12348-0160088-x

148. Goldhardt R, Patel H, Davis JL. Acute Posterior Multifocal Placoid Pigment Epitheliopathy Following Dengue Fever: A New Association for an Old Disease. Ocul Immunol Inflamm (2016) 24(6):610-4. doi: 10.3109/ 09273948.2015.1125513

149. Park JH, Joe SG, Yoon YH. Delayed Diagnosis of Ocular Syphilis That Manifested as Retinal Vasculitis and Acute Posterior Multifocal Placoid Epitheliopathy. Indian J Ophthalmol (2013) 61(11):676-8. doi: 10.4103/ 0301-4738.119415

150. Fine HF, Kim E, Flynn TE, Gomes NL, Chang S. Acute Posterior Multifocal Placoid Pigment Epitheliopathy Following Varicella Vaccination. $\mathrm{Br} J$ Ophthalmol (2010) 94(3):282-3, 363. doi: 10.1136/bjo.2008.144501

151. Borruat FX, Piguet B, Herbort CP. Acute Posterior Multifocal Placoid Pigment Epitheliopathy Following Mumps. Ocul Immunol Inflamm (1998) 6(3):189-93. doi: 10.1076/ocii.6.3.189.4038

152. Lowder CY, Foster RE, Gordon SM, Gutman FA. Acute Posterior Multifocal Placoid Pigment Epitheliopathy After Acute Group A Streptococcal Infection. Am J Ophthalmol (1996) 122(1):115-7. doi: 10.1016/S0002-9394 (14)71974-9

153. Wolf MD, Folk JC, Nelson JA, Peeples ME. Acute, Posterior, Multifocal, Placoid, Pigment Epitheliopathy and Lyme Disease. Arch Ophthalmol (1992) 110(6):750. doi: 10.1001/archopht.1992.01080180020004

154. Supramaniam A, Lui H, Bellette BM, Rudd PA, Herrero LJ. How Myeloid Cells Contribute to the Pathogenesis of Prominent Emerging Zoonotic Diseases. J Gen Virol (2018) 99(8):953-69. doi: 10.1099/jgv.0.001024

155. Medzhitov R. The Spectrum of Inflammatory Responses. Science (2021) 374 (6571):1070-5. doi: 10.1126/science.abi5200

156. Ansaldo E, Farley TK, Belkaid Y. Control of Immunity by the Microbiota. Annu Rev Immunol (2021) 39:449-79. doi: 10.1146/annurev-immunol093019-112348

157. Constantinides MG, Belkaid Y. Early-Life Imprinting of Unconventional T Cells and Tissue Homeostasis. Science (2021) 374(6573):eabf0095. doi: 10.1126/science.abf0095

Conflict of Interest: The authors declare that the research was conducted in the absence of any commercial or financial relationships that could be construed as a potential conflict of interest.

Publisher's Note: All claims expressed in this article are solely those of the authors and do not necessarily represent those of their affiliated organizations, or those of the publisher, the editors and the reviewers. Any product that may be evaluated in this article, or claim that may be made by its manufacturer, is not guaranteed or endorsed by the publisher.

Copyright (C) 2022 Forrester, Mölzer and Kuffova. This is an open-access article distributed under the terms of the Creative Commons Attribution License (CC BY). The use, distribution or reproduction in other forums is permitted, provided the original author(s) and the copyright owner(s) are credited and that the original publication in this journal is cited, in accordance with accepted academic practice. No use, distribution or reproduction is permitted which does not comply with these terms. 